\title{
Characterization of elderly people with an intestinal stoma at a reference center in the state of Bahia
}

\author{
Caracterização dos idosos com estomia intestinal atendidos em centro de \\ referência do estado da Bahia
}

\section{Caracterización de los ancianos con estoma intestinal atendidos en centro de referencia del estado de Bahia}

\author{
Lília Improta de Andrade 1 , Andrea Alves Pinho ${ }^{1}$, Alba Carolina Andrade Mascarenhas \\ Eline Lima Borges, ${ }^{2,}$, José Ferreira Pires Junior ${ }^{3}$
}

ORCID IDS

Andrade LI (iD https://orcid.org/0000-0001-9295-5127

Pinho AA (iD https://orcid.org/0000-0003-0096-5956

Mascarenhas ACA (D https://orcid.org/0000-0001-9515-9767

Borges EL (D) https://orcid.org/0000-0002-0623-5308

Pires Junior JF (iD https://orcid.org/0000-0002-6019-0198
HOW TO CITE

Andrade LI; Pinho AA; Mascarenhas ACA; Borges EL; Pires Junior JF. Characterization of elderly people with an intestinal stoma at a reference center in the state of Bahia. ESTIMA, Braz. J. Enterostomal Ther., 17, 2019: e2619. https://doi.org/10.30886/estima.v17.700_IN

\begin{abstract}
Objective: To characterize the elderly patients with intestinal stoma, enrolled in a Reference Center of the public health network of the state, regarding sociodemographic and clinical aspects. Method: This is a cross-sectional descriptive study with a sample of 33 elderly patients with intestinal stoma who met the inclusion criteria. Data were extracted from the medical record, interview and evaluation of the stoma and surrounding skin, analyzed through descriptive statistics. Results: patients underwent surgery in public and private hospitals, 54.5\% were female, 51.6\% married or in stable union, mean age was 68.03 ( \pm 7.2 ) years, 69.7\% had cancer as a cause of the stoma, $66.7 \%$ were temporary and $81.8 \%$ were colostomies. There was a predominance of stomas with a regular and round shape, diameter between 10 and $64 \mathrm{~mm}$ and a mean protrusion of $2.79 \mathrm{~mm}( \pm 5.1)$, use of a drainage bag with a cut greater than the stoma, 51.5\% for stoma and device care. Conclusion: the study allowed to identify the profile of the elderly with intestinal stoma, which will allow the adjustment of the specialized assistance planning and the provision of collecting equipment and adjuvants in the context of the state.
\end{abstract}

KEYWORDS: Colostomy; Ileostomy; Health of the elderly; Health profile; Enterostomal therapy.

\section{RESUMO}

Objetivo: Caracterizar, quanto aos aspectos sociodemográficos e clínicos, os pacientes idosos com estomia intestinal cadastrados em um Centro de Referência da rede pública de saúde. Métodos: Trata-se de uma pesquisa descritiva, transversal, com amostra de 33 pacientes idosos com estomia intestinal que atenderam aos critérios de inclusão. Os dados foram extraídos do prontuário, da entrevista e avaliação da estomia e pele ao redor, analisados por meio da estatística descritiva. Resultados: Os pacientes realizaram cirurgia em hospitais públicos e privados, 54,5\% eram do sexo feminino, 51,6\% casados ou em união estável, média de idade de $68,03( \pm 7,2)$ anos, 69,7\% tiveram câncer como causa da estomia, 66,7\% eram temporários e 81,8\% colostomias. Houve predomínio

1.Escola Bahiana de Medicina e Saúde Pública - Curso de Especialização Enfermagem em Estomaterapia - Salvador/BA - Brasil. 2.Universidade Federal de Minas Gerias - Escola de Enfermagem - Departamento de Enfermagem Básica - Belo Horizonte/MG - Brasil. 3.Universidade Federal de Minas Gerais - Escola de Enfermagem - Belo Horizonte/MG - Brasil.

*Correspondence author: eborges@ufmg.br

Received: Jan. 10, 2019 | Accepted: Nov. 11, 2019 
de estomias de formato regular e redondo, diâmetro entre 10 a 64 mm e protrusão média de 2,79 mm ( $\pm 5,1)$, utilização de bolsa drenável com recorte maior que a estomia, 51,5\% demandavam auxílio parcial ou completo para os cuidados com estomia e dispositivo. Conclusão: $\bigcirc$ estudo permitiu identificar o perfil dos idosos com estomia intestinal, o que possibilitará a adequação do planejamento da assistência especializada e da provisão de equipamentos coletores e adjuvantes no contexto do estado.

DESCRITORES: Colostomia; lleostomia; Saúde do idoso; Perfil de saúde; Estomaterapia.

\section{RESUMEN}

Objetivo: Caracterizar a los pacientes ancianos con estoma intestinal, registrados en un Centro de Referencia de la red pública de salud del estado, en cuanto a los aspectos sociodemográficos y clínicos. Método: se trata de una investigación descriptiva, transversal, con muestra de 33 pacientes ancianos con estoma intestinal que atendieron a los criterios de inclusión. Los datos fueron extraídos del prontuario, de la entrevista y evaluación del estoma y piel alrededor, analizados por medio de la estadística descriptiva. Resultados: los pacientes realizaron cirugía en hospitales públicos y privados, 54,5\% eran del sexo femenino, 51,6\% casados o en unión estable, promedio de edad de 68,03 ( \pm 7,2) años, 69,7\% tuvieron el cáncer como causa del estoma, el 66,7\% eran temporales y el 81,8\% colostomías. Se observó un predominio de estomas de formato regular y redondo, diámetro entre 10 a 64 mm y protrusión media $2,79 \mathrm{~mm}( \pm 5,1)$, utilización de bolsa drenable con recorte mayor que el estoma, 51,5\% demandaban auxilio parcial o completo para el cuidado de estoma y dispositivo. Conclusión: el estudio permitió identificar el perfil de los ancianos con estoma intestinal lo que posibilitará la adecuación de la planificación de la asistencia especializada y de la provisión de equipos colectores y adyuvantes en el contexto del estado.

DESCRIPTORES: Colostomía; Ileostomía; Salud del anciano; Perfil de salud; Estomaterapia.

\section{INTRODUCTION}

In developed countries with high income per capita, life expectancy has increased in recent decades. The decrease of some risk factors contributed to this event. The main factors are reduced tobacco consumption and mortality from cardiovascular diseases (both for men and women $)^{1}$.

Aging is part of the reality of the society in developed or developing countries, represented by the reduction of the number of children and young people and the increase of people aged 65 and over. This statement is supported by the estimate that by 2050 there will be two billion elderly people worldwide ${ }^{2}$.

Increased life expectancy, an aging population, and effective screening programs for colorectal cancer have led to an increase in the number of people with an intestinal stoma (ileostomy and colostomy) in several countries $^{3}$. Even the number of elderly people with a stoma is expected to increase in the coming years as well ${ }^{4}$.

Genetic, environmental, and lifestyle-related aspects can influence the appearance of colorectal cancer, considering that this is a multifactorial disease. The geographical differences observed in the incidence of the disease possibly reflect the adoption of western habits, especially those related to sedentarism and a diet deficient in fiber and rich in red meat ${ }^{5}$.
Several studies conducted in Brazil to characterize patients with elimination stoma identified a predominance of elderly people ${ }^{6-9}$. Despite this tendency, there are few epidemiological studies conducted exclusively with elderly patients. Therefore, it is inferred that there are differences in care demands between adult and elderly patients with a stoma.

The authors of a study on elderly people with intestinal stoma identified that these people did not accept their health conditions, culminating in treatment rejection. This attitude resulted in occupational and social damage for these patients, with loss of self-esteem and social and family isolation ${ }^{10}$.

Therefore, the present study aims to elucidate the question regarding the sociodemographic and clinical profile of elderly patients with stoma treated in the reference center of the state of Bahia, Brazil, considering the absence of these records in the official state documents.

It is expected that this study on elderly people with stoma might support the managers and nurses, especially the specialists in enterostomal therapy, in planning health actions, forecasting, provision of inputs, the assistance provided, and, finally, the organization of services for the care of elderly users. 


\section{OBJECTIVE}

The study aimed to characterize, in terms of sociodemographic and clinical aspects, elderly patients with intestinal stoma registered in a reference center of the public health network.

\section{METHODS}

It is a cross-sectional, exploratory, descriptive observational study, carried out in a Specialized Center in Rehabilitation unit (CER III, acronym in Portuguese for Centro Especializado em Reabilitação) of the Brazil's Unified Health System (SUS, acronym in Portuguese for Sistema Único de Saúde), a reference center for patients in the state of Bahia (BA). It is located in the city of Salvador, where the distribution of collector devices, adjuvants, and care of patients with stoma occurred.

From July to October 2018, when data collection for the study was conducted, 1,807 users were registered, and 1,445 attended. Of these, 1,012 (70\%) were attended by the legal representative and 433 (30\%) in person (Fig. 1).

The sample was convenient, i.e., not probabilistic, due to time and resource limitations. To participate in the study, the user complied with the following inclusion criteria: to be registered in the reference service with presential attendance, to be 60 years of age or older, to have some type of intestinal elimination stoma (ileostomy or colostomy) and to be able to answer the interview questions and undergo physical evaluation with the removal of the collector device for evaluation of the stoma and the surrounding skin.

Considering the inclusion criteria, 33 users participated in the study sample.

The data collection occurred during the nursing consultation, previously scheduled, according to the service routine, and consisted of the history (interview), evaluation of the stoma, the surrounding skin, and the device in use. The proceedings took an average of 40 to 60 minutes.

A structured form was used to record data regarding personal identification, sociodemographic (age, gender, marital status, profession/occupation, monthly income, origin, household sanitation conditions) and clinics variables (cigarettes and alcohol consumption, reason and location of the surgery, associated diseases, medication in use, general condition, form of ambulation, type and characteristics of the stoma and the surrounding skin, including presence of complications). Variables related to self-care, effluent, collector device, and its management were included.

The collected data was stored in a database created in the EpiData program, exported to the statistical software Statistical Package for the Social Sciences (SPSS), version 20.0, and analyzed using descriptive statistics.

The study was conducted by Resolution 466/2012, of the National Health Council and was approved by the Research Ethics Committee of the Federal University of Minas Gerais, Certificate of Presentation for Ethical Appreciation (CAAE) No. 49807115.0.0000.5149. The participants signed the Term of Free and Informed Consent and were guaranteed anonymity and exemption from financial charges.

\section{RESULTS}

Demographic data revealed that 18 (54.5\%) participants were women. Age ranged from 60 to 86 years, mean $68.0( \pm 7.2)$ years, where $23(69.7 \%)$ were 60 to 70 years, seven $(21.2 \%) 71$ to 80 years, and three (9.1\%) over 80 years. Regarding marital status, 17 (51.5\%) were married, or in a stable union, nine $(27.3 \%)$ were single or separated, and seven (21.2\%) were widowed.

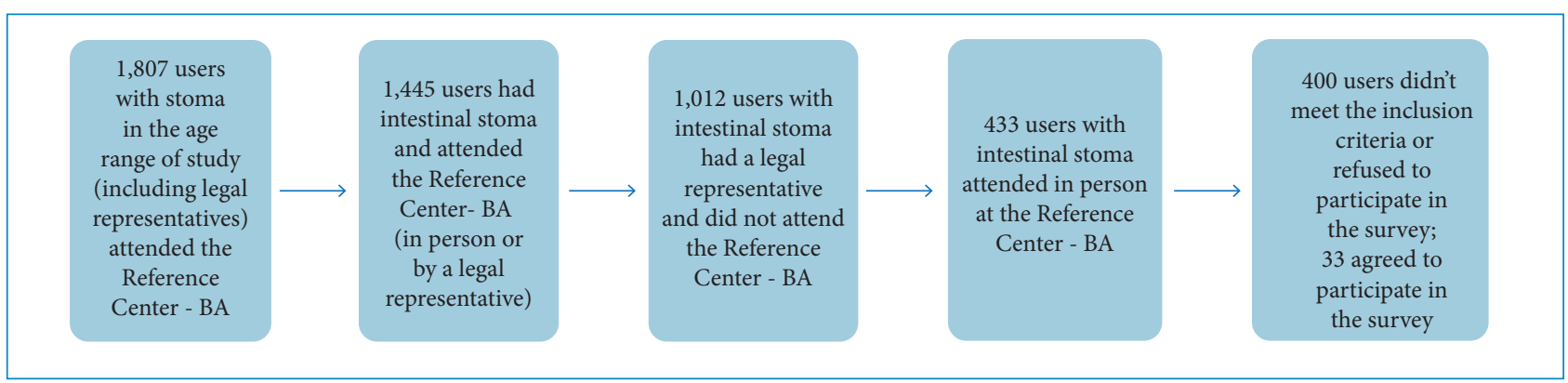

Figure 1. Sample selection process. 
As for the color declared, 13 (39.4\%) were white, 13 (39.4\%) brown, and seven (21.2\%) black.

The mean period of study of the sample was 7.4 $( \pm 3.7)$ years, ranging from 0 to 15 years, and $29(87.9 \%)$ were considered literate. Of the 33 participants, 21 (63.6\%) had between 1 and 9 years of study, seven (21.2\%) between 10 and 12 years, three (9.1\%) 13 years, and two (6.1\%) more than 13 years of study.

For the monthly income, the minimum wage (MW) number received by the participant was considered. The value of the WM was $R \$ 954.00$ during the time the study was conducted. The participants received from 1 to more than $5 \mathrm{MW}$, and the income of 23 (69.7\%) was from their retirement pension. Of the 33 participants, $20(60.6 \%)$ had an income of $1 \mathrm{MW}$, nine (27.3\%) of 2 MW, three (9.1\%) of $3 \mathrm{MW}$, and one (3.0\%) received more than $5 \mathrm{MW}$.

Regarding the place of residence, one $(3.0 \%)$ participant lived in the state of Pernambuco, in the city of Petrolina that is $500 \mathrm{~km}$ away from Salvador, where the specialized center is located; 16 (48.5\%) lived in other municipalities in the state of Bahia, two of them in Simões Filho $(27.5 \mathrm{~km})$ and one participant in each of these cities: Livramento $(722 \mathrm{~km})$, Barra $(678 \mathrm{~km})$, Piatã $(572 \mathrm{~km})$, Canarana $(538 \mathrm{~km})$, Ibipeba $(516 \mathrm{~km})$, Irecê $(481 \mathrm{~km})$, Antas (345 km), Mundo Novo (303 km),
Rio Real (208 km), Teofilândia (203 km), Madre de Deus (63 km), Mata de São João (56 km), Camaçari (41 $\mathrm{km})$. There were 16 (48.5\%) participants who lived in Salvador. The houses of four (12.1\%) participants had no treated water, sewage system, and garbage collection.

Regarding the clinical characteristics of the participants, four (12.1\%) smoked, and the number of cigarettes was 3 to 10 per day; five (15.2\%) ingested alcoholic beverages daily, and 10 (30.3\%) were in abstinence. Other clinical data are shown in Table 1.

Regarding drug treatment, 25 (75.8\%) participants used one or two drugs; 18 (51.4\%) used antihypertensive, five $(14.3 \%)$ gastric protector, three $(8.6 \%)$ oral hypoglycemic, one (2.8\%) analgesic. Regarding treatment for cancer, four (11.4\%) were under chemotherapy treatment, and four (11.4\%) under radiotherapy.

The participants performed the surgery that resulted in the stoma in public or private hospitals in Salvador, 22 (66.7\%) performed it in public, and 11 (33.3\%) in private hospitals. The time interval between hospital discharge and admission to the CER III ranged from less than one month to 12 years; for 29 (87.9\%) participants, the interval was less than one year, highlighting 21 , whose interval was shorter than one month.

At the time of data collection, participants had a stoma between less than 1 and 26 years; 13 (39.4\%)

Table 1. Clinical variables of the patients in the sample.

\begin{tabular}{|c|c|c|}
\hline Variable & Categories & n (\%) \\
\hline \multirow{7}{*}{$\begin{array}{l}\text { Disease that led } \\
\text { to the stoma surgery } \\
\text { (CID) }\end{array}$} & Rectal cancer (C20) & $21(63.7)$ \\
\hline & Acute obstructive abdomen (K56.6) & $3(9.1)$ \\
\hline & Volvo intestinal obstruction (K56.2) & $3(9.1)$ \\
\hline & Anal canal cancer (C21) & $2(6.0)$ \\
\hline & Traumatic injury in the anal region (C36.5) & $2(6.0)$ \\
\hline & Diverticulitis (K57) & $1(3.0)$ \\
\hline & Chagas disease megacolon (K93.1) & $1(3.0)$ \\
\hline \multirow{6}{*}{ Associated diseases $^{\dagger}$} & Systemic arterial hypertension & $18(48.6)$ \\
\hline & Cardiopathy & $7(18.9)$ \\
\hline & Diabetes mellitus & $5(13.5)$ \\
\hline & Depression & $3(8.1)$ \\
\hline & Obstructive pulmonary disease & $2(5.4)$ \\
\hline & Hypercholesterolemia & $2(5.4)$ \\
\hline \multirow{2}{*}{ General state } & Good & $28(84.8)$ \\
\hline & Regular & $5(15.2)$ \\
\hline \multirow{2}{*}{ Locomotion } & Independent ambulation & $31(93.9)$ \\
\hline & Ambulation with the help of prosthesis & $2(6.1)$ \\
\hline
\end{tabular}

${ }^{\dagger}$ Of the 25 patients who had associated diseases, 13 had one disease, and 12 had two diseases. 
participants had a stoma for one month or less, four (12.1\%) between 2 and 3 months, three (9.1\%) between 6 and 11 months and 13 (39.4\%) participants for more than one year. Regarding the stoma specific characteristics, all participants had only one stoma, 27 (81.8\%) had a colostomy, and 6 (18.2\%) had an ileostomy. Of the 33 stomas, 22 (66.7\%) were temporary and 11 (33.3\%) definitive, $22(66.7 \%)$ were regular and round and $6(18.2 \%)$ were irregular. The stoma diameter varied from 10 to $64 \mathrm{~mm}$, with a mean of 32.9 $\mathrm{mm}( \pm 11.3)$. The stoma protrusion ranged from 0 to $20 \mathrm{~mm}$, with a mean of $2.8 \mathrm{~mm}( \pm 5.1)$. As for the stomata location, $17(51.5 \%)$ were in the lower left quadrant.

Regarding the complications, 19 (57.6\%) participants presented from 1 to 4 complications. Of these 19, nine (47.4\%) participants presented one complication, seven (36.8\%) two complications, two (10.5\%) three complications, and one (5.3\%) presented four complications. The most frequent complications were dermatitis (48.5\%), retraction (24.2\%), prolapse (15.2\%), granuloma (6.0\%) and hernia (6.0\%).

All participants used drainable collector device, 32 of them (97.0\%) with cuttable base, whose cutout ranged from 15 to $70 \mathrm{~mm}$, and 12 (36.3\%) participants needed adjuvants, with 7 using one product (synthetic resin paste), 2 using two products (synthetic resin paste with paste or with belt), and 3 using three products (synthetic paste and powder, and belt). All participants stated that they had received a sufficient number of collectors and adjuvant devices for the established period. The number of device changes per week varied from one to seven times (Table 2).

Regarding the cutout of the collector device plate, $23(69.7 \%)$ participants had an orifice larger than the stoma, ranging from 4 to $39 \mathrm{~mm}$ (Fig. 2).

Table 2. Characteristics of devices and adjuvants used by the participants.

\begin{tabular}{|c|c|c|}
\hline Variable & Categories & n (\%) \\
\hline \multirow{2}{*}{ Number of devices } & One & $21(63.6)$ \\
\hline & Two & $12(36.4)$ \\
\hline \multirow{2}{*}{ Type of plate } & Cuttable & $32(97.0)$ \\
\hline & Pre-cut & $1(3.0)$ \\
\hline \multirow{5}{*}{ Changes/week } & 1 & $6(18.2)$ \\
\hline & 2 & $16(48.5)$ \\
\hline & 3 & $5(15.2)$ \\
\hline & 4 & $4(12.1)$ \\
\hline & 7 & $2(6.0)$ \\
\hline
\end{tabular}

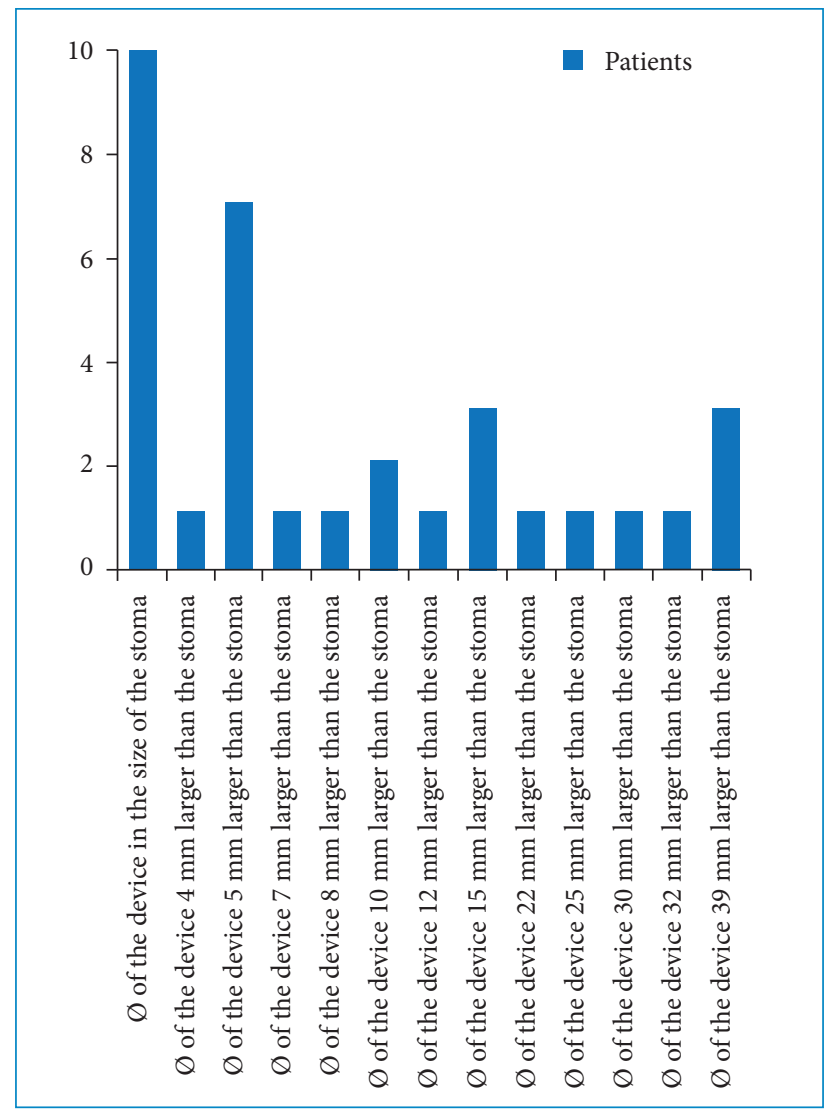

Figure 2. Device cutout diameter in relation to the size of the stoma.

Regarding the effluent consistency, 15 (45.5\%) participants presented pasty stool, 9 (27.3\%) semi-pasty, 6 (18.2\%) liquid and 3 (9.1\%) solid feces. The elimination pattern varied from one to countless times a day, with $12(36.4 \%)$ participants having two eliminations, 9 (27.3\%) four to five times, 6 (18.2\%) three times, 3 (9.1\%) countless times and 3 (9.1\%) once a day. The elimination of flatus was reported by 25 (75.8\%) participants, with 13 (39.4\%) complaining of unpleasant odor.

The nurse of the reference service periodically evaluated all participants. Regarding the self-care with the stoma and management of the device, 17 (51.5\%) participants demanded partial or complete assistance for this care, 11 (33.3\%) did not sanitize the device, and 17 (51.5\%) did not exchange it. The reason for not adequately performing self-care for 30 (90.9\%) participants was a denial of their health status, and for 3 (9.1\%), it was related to physical limitations.

\section{DISCUSSION}

The achieved results are essential for future interventions in the planning and improvement of 
care for patients with a stoma in the health service, considering the specificities of the elderly person. One result that highlighted was the non-attendance of $70 \%$ of the users to the consultation with the CER III nurse forwarding the legal representative to get the collector device. This may have occurred because the user was an elderly person who lived in a municipality up to $720 \mathrm{~km}$ away from the reference service.

Users came from many municipalities in various regions of Bahia, including one of the participants that were from the interior of the Pernambuco state (Petrolina), which borders the Bahia state. Such information demonstrates the need to structure and implement specialized service centers in the state of Bahia and other Brazilian states, providing more excellent proximity for users to seek their services. A similar data was found in the study conducted in the state of Pará, where about $38 \%$ of users attended in the capital were from municipalities in the interior of the state ${ }^{11}$.

Since 2003, the elderly Brazilians have certain rights assured by the Law no 10.741 , with emphasis on the institution of the Elderly Statute, which regulates the rights assured to people aged 60 years or more. It also ensured full attention to the health of the elderly by the Unified Health System (SUS) ${ }^{12}$. Another advance occurred in 2006 when the Ministry of Health established, together with the state and municipal health spheres, the commitment to invest in the quality of care provided by SUS to people over 60 years of age. Another highlight is the registration of the health of the elderly person as one of the SUS priority areas that happened in the same year ${ }^{2}$.

The National Health Policy of the Elderly Person brings in its guidelines conditions necessary to meet the demand of this group of people in various aspects ${ }^{13}$, including the changes resulting from aging itself that can favor the emergence of diseases such as colon and rectal cancer.

The majority of the sample was composed of elderly people from 60 to 70 years of age, with incomplete primary education, women, whose leading cause of stoma indications was neoplasia, especially colorectal cancer. This data is corroborated by other studies, which have identified cancer as the main reason for surgical interventions for an intestinal stoma. This data can justify the higher rate of colostomy-type stomata, evidenced in this and other studies ${ }^{14-17}$.
In 2017, 1,370 new cases of colon and rectal cancer were estimated to occur in the state of Bahia in $2018^{18}$. The treatment of this disease, in most cases, involves the performance of surgery that leads to the confection of an elimination stoma, i.e., ileostomy or colostomy.

Lifestyle-related risk factors include consumption of alcoholic beverages, low fruit and vegetable intake, high consumption of red meat and processed foods, obesity, smoking, and physical inactivity ${ }^{19}$.

Age is a factor that seems to contribute to colorectal cancer mortality. This data was confirmed by a study conducted in the state of Rio de Janeiro, which identified the correlation of age with the increased mortality rate due to neoplasia, considering deaths among individuals over 35 years of age between 1980 and $2014^{20}$.

The increase in the number of people aged 65 and over in relation to the number of children and adolescents is already a reality in the population in developing countries like Brazil, and it is known that the incidence and mortality of colorectal cancer increase progressively with age ${ }^{16}$. This type of cancer has epidemiological relevance worldwide, considering that it is the third most diagnosed malignant neoplasm and the fourth leading cause of cancer death. In Brazil, excluding nonmelanoma skin tumors, colon and rectal cancer in men rank fourth in the Northeast and North regions. For women, it is the third most frequent in this same regions ${ }^{18}$.

Even the patients who performed the surgery in a private hospital were referred to the SUS reference service (CER III). The assistance provided by the multiprofessional team to people with a stoma is based on the objective of achieving their rehabilitation as soon as possible. This rehabilitation involves some changes and adaptations of people affected by the problem to face the new lifestyle related to the physical, social, and psycho-emotional aspects ${ }^{21}$.

In recent years, some efforts have been made to reduce the suffering of people with a stoma, with emphasis on the Ministry of Health which, through the publication of Order No. 400/2009, established national guidelines in the scope of SUS for health care for those people who indicate the granting of collector devices ${ }^{22}$.

The professional who assists the patient with stoma must have an in-depth knowledge of the characteristics of the equipment available on the market, as well as of the stoma and the habits of life. The indication of 
the appropriate equipment for the patient is essential, considering the aspects that bring benefits such as comfort, safety, and practicality, including skin protection, proper adaptation, and permanence of the device in the peristomal region ${ }^{23}$. Access to the diversity of collector devices was not a reality for the users of the service where the study was conducted since only drainable, and plate collection bags were available, most of them cuttable. Most of the participants were in good general condition, with independence for walking, however few performed self-care with the stoma and the collector device.

A longitudinal phenomenological approach study was performed with 12 participants with a newly performed stoma. The data were collected 3, 9, and 15 months after surgery through unstructured and in-depth interviews, whose data were analyzed using an iterative customized structure. The results identified three categories: participation in the social environment, interpersonal relations - changes and challenges, and setting and achieving goals. The authors concluded that the surgery that culminates in the making of the stoma alters the ways people relate to their social environment and connect with other people, creating self-conscience and preventing social trust and autonomy. Understanding the social implications of stoma surgery can help nurses to provide appropriate and responsive support to facilitate social rehabilitation ${ }^{24}$.

The nurse, especially the enterostomal therapist, plays an important role in the rehabilitation process of people with an elimination stoma. It seems that elderly people may face more significant difficulties during this period. A review study conducted on a sample of 16 studies, whose analysis confirmed that the nurse is one of the professionals closest to the person with a stoma and his family, must act, especially when dealing with the elderly person, as a link between the patient, the family, and the multi-professional health team. In this sense, health professionals, especially the nurse, must be able and competent in assisting the various demands for the care of this population segment so that the actions are active, resolute, and, above all, fully humanized, aiming at improving the quality of life ${ }^{25}$.

It is believed that the lower the level of education, the more difficult it is to understand the conditions and adaptations necessary for rehabilitation and to achieve a satisfactory lifestyle. In most studies on the subject, the authors confirm the high occurrence of noncompletion of primary school ${ }^{14-17}$. This data was ratified in this study, showing that most users of the sample had incomplete primary education and most required partial or complete assistance for stoma and device care.

The making of a stoma is directly linked to the type of surgical intervention indicated for the treatment of the underlying disease. In this study, the stoma location in the left quadrant was predominant, justifying the predominance of oncologic diagnosis and the type of pasty effluent.

It is important to emphasize that, in order to avoid complications in the stoma and the surrounding skin, it is essential an assistance planning that includes the previous demarcation on the abdominal surface where the intestinal loop will be exteriorized. The surgical technique performed, associated with the observation of risk factors such as advanced age, weakness of abdominal muscles, increased body weight in the postoperative period, and the use of collector devices appropriate to the type of stoma ${ }^{7,17}$.

The round shape and the recommended protrusion of 3 to $5 \mathrm{~cm}$, especially for right colon and ileum stomata, can reduce complications since they favor the adaptation of the collector equipment and prevent the leak of the effluent ${ }^{15}$. The diameter of the stoma implies fundamental data for the quality care of the patient since it is essential for the correct selection of the collector device. Such conduct allows the adaptation of the skin barrier adhesive base in the stoma, thus preventing lesions of the surrounding skin, providing greater comfort.

In this study, the predominant use of the cuttable drainable bag was observed, with a cut of the resin plate more extensive than the stoma diameter. This procedure exposes the skin to the action of the effluent, reflecting directly on the result of the identified complications, of which $48.5 \%$ was dermatitis. It can be inferred that one of the probable causes for the error in the cutout is the lack of orientation or even assimilation of information due to the patients' low level of education. The finding may also have been fostered by a large number of legal representatives attending the service center on the user's behalf.

The adaptation time after the surgery is peculiar to each person with stoma ${ }^{26}$. It is noteworthy that in a study of 526 people of various ages with an intestinal stoma, the authors found that the elderly patients had no more limitations or 
psychosocial impact due to the stoma compared to their younger peers. Over the years, the impact becomes less distinct ${ }^{27}$.

In this study, it was evident that the reason for not performing self-care was mainly related to denial of health status. Similar data were obtained from a study conducted in the Netherlands, whose aged $\geq 80$ years of age needed help or assistance to empty or replace the bag, mainly due to the inability to reach or accurately visualize the stoma ${ }^{27}$.

In another study conducted in Portugal with the inclusion of 55 patients with ages ranging from 34 to 85 years, there was a general predominance of male patients with ileostomy (83.3\%), urostomy (75.0\%) and colostomy (51.7\%). The most common causes for the making of the stoma were malignant diseases (90.9\%). Colostomies and ileostomies were performed mainly due to rectal cancer $(69.0$ and $55.6 \%$, respectively). Only one case of ileostomy (5.6\%) was caused by ulcerative colitis. Urostomy was performed due to bladder cancer in all cases (100\%). Patients with ileostomy and colostomy had a significantly lower quality of life compared to patients with urostomy, mainly due to the impact on social relationships, self-esteem, and self-image ${ }^{28}$.

In this study, the limiting factors found in the collection phase were the absence of the user himself, due to the constant representation by legal representatives and/or family members in the service to receive the collector devices, the existence of only one room for consultation with the nurse, the refusal of the patient to participate in the research because he had to remove the collector device for assessment of the stoma and surrounding skin, even knowing that another device would be placed during the nursing consultation. The above reasons reinforce the need for comprehensive studies in Brazil.

The results of this study obtained from a small sample of users revealed several weaknesses that could help the health team in the actions aimed at this public formed by elderly people and allowed to establish some implications for rehabilitation:

- Helping elderly people with a stoma to develop competent stoma self-care skills will promote selfacceptance and self-care;

- Nurses should promote access to referral services for elderly people with a stoma to adapt to new living with a stoma;
- Gradual exposure to social participation can generate feelings of control and confidence for people with a stoma.

The need to reorganize the care service network, to establish strategies to improve the care provided to elderly users, in addition to ensuring the acquisition and standardization of collecting equipment and protection and safety adjuvants that meet the individual needs of these users is highlighted. Decision making in the treatment of the elderly person with an intestinal stoma is challenging, which demands strategies aimed at rehabilitation since the preoperative period.

\section{CONCLUSION}

The study identified the profile of elderly users with an intestinal stoma of the reference center of the state of Bahia. The patients presented limitations for selfcare, used a drainable device regardless of the type of stoma, the pattern of elimination, and the characteristic of the effluent. The cutout of the device plate was more significant than the diameter of the stoma, increasing the risk of dermatitis. Many were represented by a family member or a legal representative.

The findings of the study will enable the adequacy of the planning of specialized assistance, the provision of collection equipment, and adjuvants in the context of the state of Bahia.

\section{AUTHORS' CONTRIBUTION}

Conceptualization, Andrade LI, Pinho AA, and Borges EL; Methodology, Andrade LI, Pires Junior JF, and Borges EL; Investigation, Andrade LI, Pinho AA, and Mascarenhas ACA; Writing - Original Draft, Andrade LI, Pinho AA, and Mascarenhas ACA; Writing - Review and Editing, Borges EL and Pires Junior JF; Supervision, Borges EL. 


\section{REFERENCES}

1. Mathers CD, Stevens GA, Boerma T, White RA, Tobias MI. Causes of international increases in older age life expectancy. Lancet. 2015;385(9967):540-48. https://doi. org/10.1016/S0140-6736(14)60569-9

2. Brasil. Ministério da Saúde. Envelhecimento e saúde da pessoa idosa [Internet]. 2006 [cited in 09 jun. 2018]. Available at: http://bvsms.saude.gov.br/bvs/publicacoes/ evelhecimento_saude_pessoa_idosa.pdf

3. Coleman MP, Quaresma M, Berrino F, Lutz JM, Angelis R, Capocaccia R. et al. Cancer survival in five continents: a worldwide population-based study (CONCORD). Lancet Oncol. 2008;9(8):730-56. https://doi.org/10.1016/ S1470-2045(08)70179-7

4. Bretthauer M. Colorectal cancer screening. J Intern Med. 2011;270(2):87-98. https://doi.org/10.1111/j.13652796.2011.02399.x

5. Arnold M, Sierra MS, Laversanne M, Soerjomataram I, Jemal A, Bray F. Global patterns and trends in colorectal cancer incidence and mortality. Gut. 2017;66(4):683-91. https://doi.org/10.1136/gutjnl-2015-310912

6. Luz ALA, Luz MHBA, Antunes A, Oliveira GS, Andrade EMLR, Miranda SM. Perfil de pacientes estomizados: revisão integrativa da literatura. Cult de los Cuid. 2014;18(39):115-23. https://doi.org/10.7184/ cuid.2014.39.13

7. Moraes JT, Victor DR, Abdo JR, Santos MC, Perdigão MM. Caracterização dos estomizados atendidos pela secretaria municipal de saúde de Divinópolis-MG. ESTIMA, Braz J Enterostomal Ther. 2014;7(3):31-7.

8. Barbosa MH, Dal Poggetto MT, Barichello E, Cunha DF, Silva R, Alves PIC, et al. Aspectos clínicos e epidemiológicos de estomizados intestinais de um município de Minas Gerais. Rev Enferm Atenção Saúde. 2014;3(1):64-73.

9. Souza APMA, Santos IBC, Soares MJGO, Santana IO. Perfil clínico epidemiológico de los pacientes atendidos y censados en el Centro Paraibano de Ostomizados João Pessoa, Brasil. Gerokomos. 2010;21(4):183-90.

10. Barros EJL, Santos SSC, Lunardi VL, Lunardi Filho WD. Ser humano idoso estomizado e ambientes de cuidado: reflexão sob a ótica da complexidade. Rev Bras Enferm. 2012;65(5):844-8. https://doi.org/10.1590/S003471672012000500019

11. Silva AC, Silva GNS, Cunha RR. Caracterização de pessoas estomizadas atendidas em consulta de enfermagem do serviço de estomaterapia do município de Belém-PA. ESTIMA, Braz J Enterostomal Ther. 2012;10(1):20-7.

12. Brasil. Presidência da República. Lei 10.741 de 1 de outubro de 2003. Dispõe sobre o estatuto do idoso e dá outras providências [Internet]. 2003 [cited in 09 jun.
2018]. Available at http://www.planalto.gov.br/ccivil_03/ leis/2003/L10.741.htm

13. Brasil. Ministério da Saúde. Atenção à saúde da pessoa idosa e envelhecimento [Internet]. 2010 [cited in 09 jun. 2018]. Available at: http://bvsms.saude.gov.br/bvs/publicacoes/ atencao_saude_pessoa_idosa_envelhecimento_v12.pdf

14. Almeida EJ, Silva AL. Caracterização do Perfil Epidemiológico dos Estomizados em Hospitais da Secretaria de Estado de Saúde do Distrito Federal. ESTIMA, Braz J Enterostomal Ther. 2015;13(1):11-16. https://doi.org/10.5327/Z18063144201500010004

15. Miranda SM, Luz MHBA, Sonobe HME, Andrade EMLR, Moura ECC. Caracterização Sociodemográfica e Clínica de Pessoas com Estomia em Teresina. ESTIMA, Braz J Enterostomal Ther. 2016;14(1):29-35. https://doi. org/10.5327/Z1806-3144201600010005

16. Ecco L, Dantas FG, Melo MDM, Freitas LS, Medeiros LP, Costa IKF. Perfil de pacientes colostomizados na Associação dos Ostomizados do Rio Grande do Norte. ESTIMA, Braz J Enterostomal Ther. 2018;16:1-8. https:// doi.org/10.30886/estima.v16.351_PT

17. Aguiar ESS, Santos AAR, Soares MJGO, Ancelmo MNS, Santos SR. Complicações do Estoma e Pele Periestoma em Pacientes com Estomas Intestinais. ESTIMA, Braz J Enterostomal Ther. 2011;9(2).

18. Instituto Nacional de Câncer José Alencar Gomes da Silva (INCA). Estimativa 2018: incidência de câncer no Brasil [Internet]. 2018 [cited in 09 jun. 2018]. Available at: http:// www1.inca.gov.br/estimativa/2018/

19. World Cancer Research Foundation; American Institute for Cancer Research (AICR). Diet, nutrition, physical activity and colorectal cancer [Internet]. 2018 [cited in 09 jun. 2018]. Available at: http://www.aicr.org/continuous-updateproject/reports/colorectal-cancer-2017-report.pdf

20. Gasparini B, Valadão M, Miranda-Filho A, Silva CMFP. Análise do efeito idade-período-coorte na mortalidade por câncer colorretal no Estado do Rio de Janeiro, Brasil, no período 1980 a 2014. Cad Saúde Pública. 2018;34(3):1-12. https://doi.org/10.1590/0102-311×00038017

21. Nascimento CMS, Trindade GLB, Luz MHBA, Santiago RF. Vivência do paciente estomizado: uma contribuição para a assistência de enfermagem. Texto Contexto - Enferm. 2011;20(3):557-564. https://doi.org/10.1590/S010407072011000300018

22. Brasil. Ministério da Saúde. Portaria MS-SAS No 400 de 16 de novembro de 2009. Estabelece Diretrizes Nacionais para a Atenção à Saúde das Pessoas Ostomizadas no âmbito do Sistema Único de Saúde. Secretaria de Atenção à Saúde [Internet]. 2009 [cited in20 set. 2018]. Available at: http://bvsms.saude.gov.br/bvs/saudelegis/sas/2009/ prt0400_16_11_2009.html 
23. Moraes JT, Amaral CFS, Borges EL, Ribeiro MS, Guimarães EAA. Serviços de atenção ao estomizado: análise diagnóstica no Estado de Minas Gerais, Brasil. Cad Saúde Colet. 2014;22(1):101-8. https://doi.org/10.1590/1414$462 \times 201400010015$

24. Thorpe G, McArthur M. Social adaptation following intestinal stoma formation in people living at home: a longitudinal phenomenological study. Disabil Rehabil. 2017;39(22):2286-93. https://doi.org/10.1080/0963828 8.2016 .1226396

25. Santos RP, Fava SCL, Dázio EMR. Self-care of elderly people with ostomy by colorectal cancer. J Coloproctol. 2019;39(3):26573. https://doi.org/10.1016/j.jcol.2019.01.001

26. Fernandes RM, Borges EL, Donoso TV. Perfil da clientela estomizada residente no município de Ponte Nova, Minas
Gerais. Rev Bras Colo-Proctol. 2010;30(4):385-92. https://doi. org/10.1590/S0101-98802010000400001

27. Verweij NM, Hamaker ME, Zimmerman DDE, van Loon YT, van den Bos F, Pronk A, et al. The impact of an ostomy on older colorectal cancer patients: a cross-sectional survey. Int J Colorectal Dis. 2017;32(1):89-94. https://doi.org/10.1007/ s00384-016-2665-8

28. Silva JO, Gomes P, Gonçalves D, Viana C, Nogueira F, Goulart A, et al. Quality of Life (QoL) among ostomized patients - a crosssectional study using Stoma-care QoL questionnaire about the influence of some clinical and demographic data on patients' QoL. J Coloproctol. 2019;39(1):48-55. https://doi.org/10.1016/j. jcol.2018.10.00 